\title{
Farklılıklara Saygı Eğitim Programının Öğrencilerin Farklılıklara Saygı Düzeyine Etkisi
}

\author{
Tolga TOPCUBAŞI* \\ Abdurrahman Nermin Bilimli İlkokulu, Bağcılar / İstanbul / Türkiye, \\ topcubasitolga@gmail.com, ORCID:0000-0003-4660-8903

\section{Prof. Dr. Soner POLAT} \\ Kocaeli Üniversitesi, Eğitim Fakültesi, İzmit / Kocaeli / Türkiye, \\ spolat@kocaeli.edu.tr, ORCID: 0000-0003-2407-6491
}

\section{$\ddot{\mathbf{O z}}$}

Bu araştırmada, hayat bilgisi dersi 3. sınıf farklılıklara saygı kazanımları kullanılarak hazırlanan "Farklılıklara Saygı Eğitim Programı”nın öğrencilerin farklılıklara saygı tutumları düzeylerine etkisi incelenmiştir. Araştırma İstanbul ili Bağcılar ilçesinde yer alan Abdurrahman Nermin Bilimli İlkokulu'nda deney grubu için seçilen 39, kontrol grubu için seçilen 40 olmak üzere toplamda 79 üçüncü sınıf öğrencisiyle yapılmıştır. Araştırmada ön test-son test gruplu yarı deneysel yöntem kullanılmıştır. FSEP (Farkl1lıklara Saygı Eğitim Programı) uygulaması öncesi ve sonrasında öğrencilerin farkl1lıklara saygı tutumlarının düzeylerini belirlemek amacıyla Ekmişoğlu (2007) tarafından geliştirilen "Farklılıklara Saygı Tutum Ölçeği” kullanılmıştır. 2013-2014 eğitimöğretim yılı bahar yarıyılında araştırmacının öğretmen olarak görev yaptığı okulda, araştırmacının kendisi tarafindan deney grubuna 14 hafta boyunca haftada iki ders saati olmak üzere Farklılıklara Saygı Eğitimi Programı (FSEP) uygulanmıştır. Kontrol

* Sorumlu Yazar. Tel: +90 5077522810

(C) 2018 Kalem Eğitim ve Sağlık Hizmetleri Vakfı. Bütün Hakları Saklıdır. 
grubuna 14 hafta herhangi bir işlem yapılmamıştır. FSEP uygulandıktan sonra FSEP'nin deney grubuna etkisini ölçmek ve iki grup arasındaki farkı belirlemek için ön testte uygulanan farklılıklara saygı ölçeği tekrar uygulanmıştır. Araştırma bulguları, FSEP'nin uygulandığı deney grubunun farklılıklara saygı düzeyini kontrol grubuna göre daha fazla arttırdığı görülmüştür. FSEP alan deney grubu ve FSEP almayan kontrol grubunun farklılıklara saygı eğitiminin aile sosyal yapısı, cinsiyet, engel, farklı kültürel geçmiş boyutları da ayrı ayrı incelenmiştir. FSEP alan deney grubu her boyutta, ön testteki aldığı puandan ve kontrol grubundan daha yüksek puanlar almıştır. Sonuçlara bakıldığı üzere FSEP'nin öğrencilerin farklılıklara saygı tutum düzeyini geliştirmedeki olumlu etkisi âşikârdır.

Anahtar Kelimeler: Farklılık; Farklılıklara saygı eğitimi; Kültürlerarası eğitim; Ayrımcılığa karşı eğitim; Hayat bilgisi.

\title{
The Impact of Respect of Diversities Educational Programs on Student Diversity Respect Level
}

\begin{abstract}
In the present study is the impact of Respect of Diversities Educational Program (RDEP) prepared by using the $3^{\text {th }}$ grade Social Studies respect of diversities objectives on the student's respect of diversities level is assessed. The research was conducted on a total of $793^{\text {th }}$ grade students including 39 students experimental group and 40 students control group in Abdurrahman Nermin Bilimli Primary School Province of Bağcılar, İstanbul. In the study pre-test post-test group quasi-experimental method was used. "Respect of Diversities Attitude Scale" developed by Ekmişoğlu (2007) was used to assess the level of student respect of diversity attitudes before and after the RDEP implementation. RDEP was implemented on the experimental group two lessons a week for 14 weeks by the researcher himself in the school the researcher works in 2013-2014 Educational Year Spring Semester. After the implementation of RDEP, the respect of diversities scale used as pre-test was applied again to evaluate the impact of program on experimental group and to assess the difference between two groups. Results of this study shows that the experimental group which taken the RDEP the level of respect of diversities more than the control group. The impact of RDEP on family, social structure, gender, disability and diverse background dimensions of program to experimental group and to control group
\end{abstract}


individually. Program taken experimental group got higher points in all areas than both the pre-test and the control group. As seen from the results the positive impact of the RDEP on improving the level of student respect of diversity attitudes is obvious.

Keywords: Diversity; Education of diversity respect; Intercultural education; Education against discrimination; Social studies.

\section{Extended Summary}

\section{Purpose}

In a world that is increasingly globalizing, it turned into a place where different races and ethnic groups live together in many cultures. In order to the societies live together in a wealthy life, the societies should internalize their cultures and respect each other's differences. In this regard, "multiculturalism" and "respect for differences" is one of the biggest problems of our developing world. Within this context, the implementation of trainings for respect for differences in the primary education program has become inevitable. Our research thoughts highlight the importance of seeing differences as wealth not an obstacle and importance of training requirement for respect for differences.

After examination of students' behaviors who received trainings of respect for, the usefulness of this training was proven. For this purpose, in this research, by using on $3^{\text {rd }}$ Grade Social Science acquisitions of respect for differences the prepared Training for Respect of Differences Program's effects on respect behavior dimension and sub-dimensions (differences in family social structure, gender differences, disability differences, and different cultural backgrounds) were examined separately.

\section{Method}

The Research has been conducted with 79 third grade students in total, 39 of whom were selected for the experimental group and 40 of whom were selected for the control group of Abdurrahman Nermin Bilimli Elementary School located in Bağcilar District of İstanbul. In the study, pre-test and posttest group have been organized and semi-experimental method was applied. Before and after the implementation of the RDTP (Respect for Differences Training Program), in order to determine the levels of respect behaviors of students, the "Respect for Diversity Attitude Scale" developed by Ekmişoğlu (2007) was used. During the spring semester of the 2013-2014 academic year, the researcher's classeswhich $\mathrm{s} / \mathrm{he}$ is teacher himself, the Respect for 
Differences Training Program (RDTP) for twice in a week for 14. The control group was not operated for 14 weeks. Once the RDTP was applied, the scale was performed again in order to determine the effect of the RDTP on the test group and to differentiate between the two groups.

\section{Results}

After the results obtained, there was a significant difference observed between the test group which is the group that RDTP has applied and the control group, and it shows that after the training, the test group's score increased more than the control group. There is also a significant difference in favor of the test group between the test group's score and the control group's score. Gender, disability, and different cultural backgrounds of the both test and control group has not taken the training also examined separately. The RDTP trained group obtained higher scores in the dimensions of family social structure, gender, disability, different cultural background, compared to their previous test score before the RDTP and compared to the control group's test score. As the results show that the Respect for Differences Training Program enable students develop their behaviors of respect for differences in every dimension.

\section{Discussion}

According to the findings of this research, there was an increase in not only the test group's score but also the control group's score, that was not trained for the Respect for Differences Training Program. The reason for this increase may results from the fact that the teachers working based on the National Education Program, have provided assets of respect for the differences and may be the students' behaviors towards the differences in the school have been positively developed in an implicit way. But the increase in the test group in which the Respect for Differences Training Program has been conducted, is much higher. This means that instead of applying the acquisitions that were planned by the national education program only when it is needed to increase respect to differences behaviors of the students, it is more influential to apply the Training of Respecting Differences regularly every week and at the same time, making these training materials enjoyable, applying different teaching techniques in order to increase students' respect to differences levels.

\section{Conclusion}

The first hypothesis of the study was that "The level of respect to differences in the post-test results of students in the test group in which the RDTP 
was performed will be significantly increased compared to the pre-test results.". Findings in relation to hypothesis show that respect to differences level of RDTP's test group students are affected. The level of respect of the test group to the differences increased significantly compared to before RDTP implementation. Thus, the first hypothesis of the research was confirmed.

The second hypothesis of the study was that "There is a significant difference between the last test scores of RDTP-applied tests group and the non$R D T P$-applied control group students regarding the level of respect to differences.". There is a significant difference between the last-test scores of test and control groups, however, previously there was no significant difference between the initial-test scores of both groups. According to the findings, it is confirmed that the students who received the RDTP have results which are favoring the RDTP compared to the students who did not receive RDTP. These results show that the second hypothesis of research is confirmed.

The third hypothesis of the study was that "There is a significant difference in between the first-test and last-test scores in the RDTP-applied test group regarding the respect for differences dimensions (family social structure differences, gender differences, disability differences, different cultural background differences) of the students.". Findings about this hypothesis seem as favoring RDTP. The dimensions of the FSEP's test group respect to differences such as family social structure differences, gender differences, disability differences, different cultural background were affected as well. The level of respect to differences of RDTP test group such as family social structure differences, gender differences, disability differences, and different cultural background differences dimensionsincreased significantlycompared to the control group who did not receive RDTP.

The last hypothesis of the study is that "There is a significant difference between the last-test scores of the levels of respect to differences (family social structure differences, gender differences, disability differences, different cultural background differences) between the RDTP-applied test group and the control group who did not receive RDTP.". Findings of this hypothesis determine that students' family social structure differences, gender differences, disability differences, different cultural background differences are influenced as well. The level of respect to differences belonging to the RDTP applied test group in dimensions of family social structure differences, gender differences, disability differences, different cultural background differences significantly 
increased in last-test scoresin arithmetic average compared to control group. Within these results, the last hypothesis of the research was confirmed.

\section{Giriş}

Küreselleşen dünya, farklı 1rk ve etnik grupların, çeşitli kültürlerin bir arada yaşadığ 1 bir yer hâline gelmiş̧ir. Toplumların bir arada refah içinde yaşaması için de bu toplumların birbirlerinin kültürlerini benimseyerek ve birbirlerinin farklılıklarına saygı duyarak yaşamaları gerekmektedir. Bu anlamda düşünüldüğünde "çok kültürlülük” ve "farklılıklara saygı" gelişen dünyamızın en büyük sorunlarından biridir. Farklı ırkların, farklı kültürlerin, birbirlerinden farklı özelliklerde olan insanların ve toplulukların bir arada mutlu ve huzurlu bir şekilde yaşamasını sağlamak için farklılıklara saygı göstermenin benimsenmesi ve öğrenilmesi gereklidir (KEDV, 2006).

Farklılıklara sahip toplumların artmasıyla bu farklılıkların içinde barışç1l, demokratik ve huzur içinde yaşamak da artık önemli bir sorun hâline gelmiştir. Toplumların bunu başarabilmesi için yapılacak ilk iş, eğitim yaklaş1mının bu çoğulculuğu benimsemesidir. Eğitim sistemleri, öğrencileri farkl1lıkları kabul edip saygı duyacak seviyeye getirerek, o toplumda farklılıklara sayg1 duyan bireyler yetişmesine imkân sağlar. Eğitim sisteminde farklı öğrencilerin kimliklerini kabul edip saygı duymak için yapılacak ilk iş, onların kültürlerini tanıyıp sınıf içinde bu farklı kültürleri de vurgulamak olmalıdır (Yıldız, 2008). Çeşitliliğin yadsınamaz olduğu bu dünyada bireyin çok kültürlü bir kişiliğe sahip olması, karşılaştıkları kişilerle olumlu ilişkiler kurması kaçınılmaz bir durum olmuştur. Eğitimcilerin cevap aradığı en temel sorunlarından biri hâline gelen bu durum farklılıklara saygı eğitiminin doğmasına neden olmuştur (Ekmişoğlu, 2007).

Farklılıklara saygı eğitimi yabancı alanyazında "anti bias curriculum" yani "önyargı karşı1tı program” diye geçmektedir. Bu yaklaşım her bireyin önyargılara sahip olduğunu, bu önyargıların da toplumun süregelen kalıplaşmış fikirlerinden oluştuğunu savunur. Bu programda da bireylerin önyargı ve ayrımcı tutumlarının giderilmesi amaçlanır. Farklılıklara saygı yaklaşımı tüm ayrımcılık konularına karşı hassastır. Bu yaklaşımda sadece etnik ve ırksal niteliklerin değil, cinsiyet, cinsel tercihler, fiziksel ve ruhsal sağlik ya da sosyal sınıf farklılıklarının da rolü göz önünde bulundurulmaktadır (Üner, 2011).

Ramsey (1987)'e göre farklılıklara saygı eğitim programı, çok kültürlü eğitimin insan kültürünün farklılıklarına dayalı birçok boyutunu 
kapsamaktadır. Irk, meslek, sosyo-ekonomik statü, yaş, cinsiyet, cinsel tercih ve çeşitli fiziksel özellikleri ve ihtiyaçlar bu boyutlar arasındadır (Üner, 2011).

İnsanlar arasındaki bazı farklılıklar önyargılar nedeniyle ayrımcı tutumlara dönüşebilmektedir. Bu durum da insanlar arasında anlaşmazlıklara ve çatışmalara neden olmaktadır. Çocuklar küçük yaşlarda etrafındaki önemli kişilerin farklı1ıklara karşı taşıdıkları önyargıları kabul eder. Bu önyargılar, zamanla bireyleri ya da grupları çeşitli özelliklerinden dolayı dışlama ya da üstün tutmaya, yani ayrımcılığa kadar gidebilir. Bu önyargılarla mücadelenin en etkili yolu çocuğun eğitim sürecinde farklılıklara saygı eğitimi almasıdır (Ekmişoğlu, 2007).

Önyarg1 ve ayrımcılık, farklılıklara sahip olan toplumların huzurlu ve mutlu bir şekilde yaşamasına engel olan en önemli nedenlerdir. İnsanlar ait oldukları toplumların hakkında yeterli bilgi ve deneyime sahip olduklarından, kendi toplumlarına karşı olumlu tutum geliştirirken farklı toplumlar hakkında yeterli bilgi ve deneyime sahip olmadıklarından o toplumlara karşı önyargı ve tutum geliştirebilirler. Bu önyargı ve tutumlar olumlu olabileceği gibi olumsuz yargilar da olabilir. Farklı toplumlar hakkında yeterli bilgi sahibi olmayanlar o toplumlar hakkında iyi, kötü, çirkin, tehlikeli, dost, düşman gibi kalıplaşmış önyargılar oluşturabilirler (KEDV, 2006).

Çocuklar, kendilerinden farklı kişi ve gruplara karşı önyargı oluşturmayı öncelikle ailelerinden, etraflarındaki yetişkinlerden ve akran gruplarından öğrenirler. Bu önyargılar çocukların insanları dış görünüşüne, ırkına, cinsiyetine, etnik kökenine göre ayırmasına neden olur. Çocukların kendilerine benzeyenleri severken kendilerine benzemeyenleri sevmemeyi de küçük yaşta ebeveynlerinden öğrenirler. Çünkü yetişkinler istemli ya da istemsiz olarak farklı1ıklara karşı oluşturmuş olduğu kendi kalıplaşmış yargılarını çocuklara da aktarırlar. Bunun dışında çocuğun etrafindaki yetişkinlerin farklılıklara karşı göstermiş olduğu tepkiler de çocuk tarafindan örnek alınır (DermanSparks, 1989). Çocukların farklılıklara karşı önyargı oluşturmasının nedenlerinden birisi de kitle iletişim araçlarıdır. Çocukların filmlerde, televizyon programlarında, gazetelerde farklı toplumlar ve etnik gruplarla ilgili gördüğü olumsuz haberler, çocuğun bu etnik gruba karş1 olumsuz ön yarg1 oluşturmasina neden olmaktadır (KEDV, 2006).

Çocuğun farklılıklara karşı olumsuz tutumlara sahip çevresinden etkilenmemesi, farklı1ıklara ön yargıyla değil de hoşgörüyle yaklaşılması gerektiğini öğrenmesi için, farklılıklara saygı eğitimi alması önemlidir. Farklılıklara 
sayg1 eğitimi küçük yaştan itibaren başlanarak her sınıf düzeyine uygun şekilde verilmelidir. Farklılıklara saygı eğitimi ile çocuk farklı gruplara karşı oluşturduğu kalıp yargıları ortadan kaldırabilir ve farklılıklara karşı daha sayg1lı olmaya çalışabilir. Farklılıklara saygı eğitiminde öğretmenle birlikte aileye de büyük görevler düşmektedir. Öğretmen öğrenciyle beraber aileleri de farklılıklara saygı konusunda bilinçlendirmeye yönelik çalışmalar yapmalıdır (Hall, 1999).

Bireyleri birbirinden ayıran; yaş, cinsiyet, engellilik, etnik köken, dinî ve siyasî düşünce çeşitli farklı1ıkları kapsamaktadır. Bu farklılıkların bir kısmı doğuştan kazanılırken, bir kısmı da sonradan edinilmektedir. Toplumsal hayatta refah düzeyini arttırmak, daha hoşgörülü ve saygilı bir ortam oluşturmak için bireylerin farklılıkları tanımaları ve bunlara duyarlı olmaları gerekmektedir. Aslında insanların birbirinden; yaş, cinsiyet, 1rk, mezhep, ekonomik ve kültürel farklılıklar olarak ayrılması insanlığın doğasında vardır. İnsanın doğasında var olan farklılıkların farkına varması ve bunlara önyargılla bakmaması toplumu daha huzurlu bir hâle getirebilir (Atasoy, 2012).

Eğitimin hedefi bireyin toplumla bir bütün hâline gelmesini sağlamak ve toplumun gelişmesini sağlayan faydalı sorumlu vatandaşlar yetiştirmektir. Farklılıklara saygı eğitimi ile amaçlanan kendilerinin ve diğer kültürlerin değer yargılarını yorumlayabilen bireyler yetiştirmektir (Çubukçu ve Gültekin, 2002).

Küreselleşmenin hızla arttığı bir dünyada genç nesillerin farklı kültürleri tanıyan, onlarla iletişim kurmaya hazırlıklı, dünyaya açık, önyargısız, hoşgörülü ve demokratik bireyler olarak yetiştirmek gereği yadsınamaz. Bunlarla birlikte öğrencilerin içinde yaşadığımız demokratik toplumun sosyolojik ve siyasal unsurlarını tanıyan, kültürel farklılıklarını bilen, demokratik ve uzlaşmacı bireyler olarak yetişmelerini sağlamak için farklılıklara saygı eğitimine ihtiyaç duyulmaktadır (Toprak, 2008).

İnsanoğlunun toplum içinde taşıdığı bazı roller vardır. Bu roller insanların doğumundan itibaren kişiliğinin gelişmesinde son derece önemlidir. Bireyin kişilik gelişiminde bu rollerin önemi kadar eğitim sürecinin de kişilik gelişimindeki önemi büyüktür. Bu nedenle farklılıklara sayg1 eğitiminin en önemli amaçlarından birisi de bireyin olumlu bir kişilik oluşturabilmesini sağlamaktır (Derman-Sparks, 2008'den akt; Üner, 2011). Farkl11ıklara sayg1 eğitimi bireyin kendini daha iyi tanımasını sağlayarak kişiliğinin korunmasına yardımcı olur. Kişinin "ben kimim, karşımdaki kim, ben kendimi nasıl 
görüyorum, arkadaşlarım beni nasıl görüyorlar” sorularına cevap bulmalarını sağlar. Bireyin toplum tarafindan kişiliğinin onaylanması çocuğun kendi kişiliğine güvenini arttırarak ayrımcılıkla daha az karşılaşmasını sağlar (Gomolla ve Radtke, 2002).

Farklı1ıklara saygı eğitim programının amacı çocuğun farklılıkları, çeşitliliği keşfetmesini sağlayarak bu farklılıklara karşı ön yargılarının oluşmasını engellemek ve farkl1lıkların bir zenginlik olduğu duygusunu onlara yaşatmaktır. Farklılıklara sayg1 eğitim programı, toplumda kültürel çeşitlilik ve farklılıklara saygı bilincini geliştirerek ayrımcılığın azaltılmasına katkıda bulunur. Farklılıklara saygı eğitiminde kendini ve başkalarını tanıma, empati kurma ve ayrımcılığa karşı dikkat geliştirme, ayrımcılığ önleyici adımlar atma gibi süreçler mevcuttur (KEDV, 2006).

Farklılıklara saygı eğitim programının amaçları arasında bireyin öncelikle kendine güvenen bir kimlik yapılandırması yer alır. Çocukların farklılıkları olan bireylere karşı önyargısız yaklaşması ve kendisini onların yerine koyarak düşünebilmesini sağlamak da bu programın amaçları arasındadır. Bununla birlikte çocukların önyargılara karşı empatik bir tutum sergileyerek eleştirel düşünmesini sağlamak ve ayrımcılıklara karşı direnme becerilerini kazandırmak farklılıklara sayg1 eğitimi programının kazandırmaya çalıştırdığ 1 amaçlardandır (Derman-Sparks, 2010). Farklılıklara sayg1 eğitimi bireyin yaşadığı toplumdaki kültürel değerleri ve genel tutumları ayrımcılık yanlısı davranışlardan arındırarak objektif bir şekilde öğrenmesini sağlar (Üner, 2011).

Ayrımcılığa karşı eğitim gereklidir; çünkü çocuklar her istediklerinin olabileceği, henüz eşit firsatlara sahip bir yer olmayan dünyada yaşıyorlar. Çocukların çoğu kimliklerinde kendilerini güvende ve sağlam hissetmeye, okullarda kendilerini evde gibi hissetmeye ihtiyaçları vardır. Yine çocuklar kimliklerindeki, çeşitlilikteki ve önyargıdaki karışı sorunları yönlendirmek için araçlara ve öğrenebilsinler, başarabilsinler diye günlük hayatlarında güce de ihtiyaç duyarlar. İşte çocukların bu ihtiyaçlarını gidermek için farklılıklara sayg1 eğitimi önemlilik arz etmektedir (Derman-Sparks ve Edwards, 2010).

Farklılıklara sayg1 eğitim programı öğrencilerin farklılıklara ilişkin olumlu tutum besleme ve tüm insanlara saygı ile davranma konusunda yardımcı olabilmektedir. Sadece öğrenciler arasında değil ayrıca aile ve diğer sosyal ortamlardaki bireysel ve grupsal kimlik gelişimini olumlu yönde besleyebilmektedir. Farklılıklara saygı programının eğitimde dikkate alınmasıyla önyarg1 ve adaletsizliğin giderilebilmesi sağlanabilir (Wolpert, 2002). 
Farklılıklara saygı eğitimi alan öğrenci kim olduğuna ilişkin algılarından gurur duyarak özsaygılarının gelişmesine katkıda bulunur. Bunun yanında farkılıklara saygı eğitiminin diğerlerine saygı duymak, olayları farklı açılardan görebilmek, farklılıklarla etkileşimde başarılı olmak, sorunlarını çoklu bakış açısıyla ve yaratıcılıkla çözebilmek, eleştirel düşünme becerileri geliştirme yeteneği geliştirmek, önyargı ve adaletsizlikleri tanıyabilme ve bunlara karşı koyabilme yeteneği geliştirmek, işbirliği ve dayanışma yeteneğini geliştirme vb. gibi olumlu gelişim özelliklerini kazandırmada etkili olduğu söylenebilir (Wolpert, 2002).

Davis (2002), Afrika ve Latin kökenli öğrenci oranının yüksek olduğu yüksek okul/üniversitelerde neden bazı okulların diğerlerine göre daha başarılı olduğunu araştırmıştır. Başarılı okullar pozitif ayrımcılığa geniş yer vermekte, farklı 1rklardaki kişileri müfredat ve ortak müfredat konularına dâhil etmektedir. Bu okullardaki başarının sırrının da farklılıklara saygı eğitimi olduğu görülmektedir (akt; Atasoy, 2012).

Buna bağlı olarak ilköğretim programında farklılıklara sayg1 eğitimi uygulanması kaçınılmaz bir hâle gelmiştir. Bu düşüncelerden hareketle araştırmamız, toplumumuzun farklılıkları bir engel olarak değil de bir zenginlik olarak algılaması ve her türlü farklılığa saygı duymasını sağlaması için farklılıklara saygı eğitiminin önemini vurgulamıştır. Farklılıklara saygı eğitimi alan öğrencilerin farklılıklara saygı tutumları incelenerek bu eğitimin işe yararlığ 1 verilerle gözler önüne serilmiştir.

Ülkemizde 2005-2006 y1lında uygulamaya konulan ve yapılandırmacı yaklaşımı esas alan yeni ilköğretim programında farklılıklara saygı kavramı yer almaktadır. Farklılıklara saygı kazanımları ilköğretim programında en fazla hayat bilgisi ve sosyal bilgiler derslerinde yer almaktadır. Bunun dışındaki derslerde de farklılıklara saygı kazanımları mevcuttur. Farklı1ıklara sayg 1 eğitimi yeni öğretim programında değerler eğitimi kapsamında da öğrencilere kazandırılmaya çalışılmaktadır. Farklılıklara saygı duyma yeni programda kazandırılmak istenen becerilerin içinde yer almaktadır. Farklılıklara saygı duyma becerisi yapılandırmacı programda şu maddelerle açıklanmaktadır (TTKB):

- Aynı, benzer ve farklı sözcüklerini anlama ve ayırt etme

- Tüm insanların benzer ve farklı özellikleri olabileceğini fark etme

- Farklı1ıkların hayatı zenginleştirdiğini kavrama 
- Farklılığın göreceli bir kavram olduğunu fark etme

- Engelli insanların farklı gereksinimlerine karşı duyarlı olma

Yapılan alanyazın araştırmasında ülkemizde farklılıklara saygı eğitimiyle ilgili ilköğretimde deneysel bir çalışmanın olmaması da araştırmanın bir başka önemini ifade eder. Ülkemizde ilgili araştırmaların sınırlı sayıda olduğu düşünülürse, yapılan çalışmanın alanyazına ve bundan sonraki araştırmacılara katkıda bulunması açısından, bu araştırma önemli görülmektedir.

$\mathrm{Bu}$ araştırmada, "Farklılıklara Saygı Eğitimi Programı”nın öğrencilerin farklı1ıklara saygı tutumuna etkisi araştırılmıştır. Bu amaçla şu sorulara cevap aranmaktadir:

A. Uygulanan Farklılıklara Saygı Eğitim Programı öğrencilerin farkl1lıklara saygı düzeylerine etki etmekte midir?

A.1. FSEP (Farklılıklara Sayg1 Eğitim Programı) uygulanan deney grubu öğrencilerinin "Farkl1lıklara Sayg1 Düzeyi” ön test-son test puanları arasında anlamlı bir farklılık var midır?

A.2. FSEP (Farklılıklara Sayg1 Eğitim Programı) uygulanan deney grubu öğrencileri ve FSEP uygulanmayan kontrol grubu öğrencileri arasında, "Farklılıklara Saygı Düzeyi" bakımından anlamlı bir fark var midir?

B. Uygulanan Farklı1ıklara Saygı Eğitimi Programı "Farklılıklara Saygı Ölçeği Alt Boyutları (aile sosyal yapı farklılıkları, cinsiyet farklılıkları, engel farklılıkları, farklı kültürel geçmiş farklılıkları)" düzeylerine etki etmekte midir?

B.1. FSEP (Farklılıklara Saygı Eğitim Programı) uygulanan deney grubu öğrencilerinin "Farklılıklara Saygı Ölçeği Alt Boyutları (aile sosyal yapı farkl11ıkları, cinsiyet farklılıkları, engel farklılıkları, farklı kültürel geçmiş farklılıkları)" ön test ve son test puanları arasında anlamlı bir fark var midir?

B.2. FSEP (Farklılıklara Saygı Eğitim Programı) uygulanan deney grubu öğrencileri ve FSEP uygulanmayan kontrol grubu öğrencileri arasında, "Farklılıklara Saygı Ölçeği Alt Boyutları" (aile sosyal yapı farkl11ıkları, cinsiyet farklılıkları, engel farklılıkları, farklı kültürel geçmiş farklılıkları) düzeyleri bakımından anlamlı bir fark var mıdır? 


\section{Yöntem}

\section{Araştırma Deseni}

$\mathrm{Bu}$ araştırma, ön test-son test kontrol gruplu yarı-deneysel desene göre tasarlanmıştır. Yarı-deneysel modeller, gerçek deneysel modellerin gerektirdiği kontrollerin sağlanamadığı veya yeterli olmadığg durumlarda tercih edilir (Büyüköztürk, 20014; Karasar, 2012). Bu desende katılımcılar, kendiliğinden oluşmuş gruplar arasından eşleştirilmeye çalışılır. Bu çerçevede araştırmada; katılımcıların deney ve kontrol gruplarına rastgele atama şansının olmamasından dolayı yarı-deneysel desen kullanılmıştır. Ön-test-son-test kontrol gruplu desen güçlü bir araştırma modeli olmakla birlikte araştırmada kullanılan ölçme araçlarının gruplara iki kez verilmesinden dolayı deneklerin duyarlıl1ğında azalma tehlikesi gibi bir dizi zayıflıkları da içinde barındırmaktadır (Büyüköztürk, Çakmak, Akgün, Karadeniz ve Demirel, 2009).

\section{Evren ve Örneklem}

Araştırma İstanbul ili Bağcılar ilçesinde bulunan Millî Eğitim Bakanlığı'na bağlı bir ilkokulda deney grubu için seçilen 39, kontrol grubu için seçilen 40 olmak üzere toplamda 79 üçüncü sınıf öğrencileriyle yapılmıştır. Araştırmada yer alan 79 öğrenci araştırmanın örneklemini oluşturmaktadır. Örneklem seçilirken araştırmacının kendi görev yaptığı okulda seviye olarak yakın sınıflar seçilmiştir. Bu anlamda araştırmada kolay ulaşılabilir örneklem yöntemi kullanılmıştır.

Araştırmada deney ve kontrol grubu olarak seçilen iki şube, farklılıklara saygı tutumları bakımından yakın olan sınıflardan seçilmiştir. Bölge iş sahası bakımından cazip bir bölge olduğu için doğudan çok fazla göç almıştır. Bölgeye farklı illerden yapılan göçlerle birlikte etnik yapılar farklılaşmıştır. Deney ve kontrol grubu için seçilen sınıfların bu anlamda da benzer özelliklere sahip olmalarına dikkat edilmiştir.

\section{Veri Toplama Araçları}

$\mathrm{Bu}$ araştırmada, veri toplama aracı olarak "Farklılıklara Saygı Tutum Ölçeği” kullanılmıştır. FSEP uygulaması önce ve sonrasında ilkokul üçüncü sınıf öğrencilerinin farklılıklara saygı düzeylerini ölçmek için Ekmişoğlu (2007) tarafından geliştirilen "Farklılıklara Saygı Tutum Ölçeği”" kullanılmıştır. Uyarlanan ölçekte toplam 30 madde bulunmaktadır. Maddeler 3'lü likert tipi ölçeğine göre işaretlenmektedir. "Katılmıyorum" seçeneğine 1, "Biraz Kat1lıyorum" seçeneğine 2, "Katılıyorum" seçeneğine 3 puan verilen ölçekte yanıtlanan puanların toplanmasıyla toplam puan elde edilmektedir. Ölçekten 
alınabilecek en yüksek puan 90, en düşük puan ise 30 olarak hesaplanmıştır. Puanların yüksek olması öğrencilerin farklılıklara saygı düzeylerinin yüksek olduğunu ifade etmektedir. Uyarlanan ölçek 4 boyut ve 30 maddeden oluşmaktadır. Ölçekte farklılık alanlarına ilişkin olarak cinsiyet farklılıkları boyutuna yönelik 5 madde, aile-sosyal hayat farklılıkları boyutuna yönelik 9 madde, engel durumu farklılıkları boyutuna yönelik 8 madde ve farklı kültürel geçmiş durumu farklılıkları boyutuna yönelik 8 madde yer almaktadır.

\section{Uygulama ve Verilerin Analizi}

İlkokul 3. sınıf hayat bilgisi öğretim programındaki farklılıklara saygı ile ilgili kazanımlar belirlenip tüm bu kazanımlara ait FSEP hazırlanmıştır. 2013-2014 eğitim-öğretim y1lı bahar yarıyılında araştırmacının öğretmen olarak görev yaptığı okulda araştırmacının kendisi tarafından deney grubuna 14 hafta boyunca haftada iki ders saati olmak üzere Farklılıklara Saygı Eğitimi Programı (FSEP) uygulanmıştır. Kontrol grubuna 14 hafta süresinde herhangi bir işlem yapılmamıştır. FSEP uygulandıktan sonra FSEP'nin deney grubuna etkisini ölçmek ve iki grup arasındaki farkı belirlemek için ön testte uygulanan farklılıklara saygı ölçeği tekrar uygulanmıştır.

$\mathrm{Bu}$ araştırmada nicel veri teknikleri kullanılmıştır. Araştırmada FSEP öncesi ve sonrasında, deney ve kontrol grubunda yer alan öğrencilerin farkl1lıklara saygı tutum düzeylerini ölçmek amaciyla öğrencilere "Farklılıklara Saygı Tutum Ölçeği” uygulanmıştır. Ölçekler işlem öncesinde deney ve kontrol gruplarına uygulanmış, deney grubu FSEP'yi aldıktan sonra her iki gruba tekrar uygulanmıştır. Çalışmada ön test-son test gruplu yarı deneysel desen kullanıldığı için, deneysel işlem etkisini ölçme amaçlı bir analiz programı kullanılmıştır. Araştırmada elde edilen veriler SPSS (Statistical Package for Social Sciences for Windows 17.0) programı kullanılarak analiz edilmiştir. Verileri değerlendirilirken tanımlayıcı istatistiksel metotları (sayı, yüzde, ortalama, standart sapma) kullanılmıştır. Niceliksel verilerin karşılaştırılmasında iki grup arasındaki farkı bağımsız gruplarda $t$ testi, grup içi karşılaştırmalarda eşleşmiş (bağımlı) $t$ testi kullanılmıştır.

\section{Bulgular}

Araştırmanın bu bölümünde farklılıklara sayg1 eğitimi uygulanan öğrencilerin farklılıklara saygı düzeyine etkisine yönelik iki hipotez test edilmeye çalışılmıştır. Bu hipotezler; "FSEP uygulanan deney grubundaki öğrencilerin farklılıklara saygı düzeyi son test puanları ön test puanlarına göre anlamlı bir düzeyde artacaktır." ve "FSEP uygulanan deney grubu öğrencileri ve 
FSEP uygulanmayan kontrol grubu öğrencileri arasında, farklılıklara saygı düzeyleri son test puanları arasında deney grubu lehine anlamlı bir farklılık vardır." şeklinde kurulmuştur. Araştırmanın farklılara saygı düzeyi ile ilgili hipotezlerini test etmek için FSEP uygulanan deney grubu ile FSEP uygulanmayan kontrol grubunun, deney grubuna FSEP uygulandiktan sonraki durumları incelenmiştir. Grup değişkenine göre yapılan $t$ testi sonucunda şu sonuçlar elde edilmiştir:

Tablo 1. Farklılıklara Sayg1 Düzeyi Ön Test ve Son Test Ortalamalarının Deney ve Kontrol Grubuna göre $t$ Testi Kullanılarak Karşılaştırılması

\begin{tabular}{|c|c|c|c|c|c|c|c|c|c|c|c|}
\hline $\begin{array}{l}\text { Ön Test } \\
\text { Grubu }\end{array}$ & $\mathbf{N}$ & $\bar{x}$ & ss & $\mathbf{t}$ & $p$ & $\begin{array}{l}\text { Son Test } \\
\text { Grubu }\end{array}$ & $\mathbf{N}$ & $\overline{\boldsymbol{x}}$ & ss & $\mathbf{t}$ & $p$ \\
\hline Deney & 39 & 65.61 & 7.30 & & 27 & Deney & 39 & 79.56 & 4.98 & & 0 \\
\hline Kontrol & 40 & 63.85 & 7.07 & & & Kontrol & 40 & 68.17 & 6.52 & & .00 \\
\hline
\end{tabular}

Tablo 1'de deney grubu ve kontrol grubuna yapılan ön test ile iki grubun farklılara saygı düzeyleri bakımından anlamlı bir farkın bulunup bulunmadığına bakılmıştır. Tablo 1'de de görüldüğü gibi deney grubunun ortalamas1 $(\bar{x}=65.61)$ iken, kontrol grubunun ortalamas1 ( $\bar{x}=63.85)$ 'dir. Ön test puanları gruba (deney grubu ve kontrol grubu) göre anlamlı bir farklılık göstermemiştir ( $\mathrm{t}=1.091, p=0.27>0.05)$. Bu bulgu her iki grubun deney öncesi farkl1lkklara saygı düzeylerinin denk olduğu şeklinde yorumlanabilir.

Farklılıklara sayg1 düzeyleri genel olarak değerlendirildiğinde, FSEP alan deney grubu ile bu eğitimi almayan kontrol grubunun program uygulandıktan sonraki farklılıklara saygı düzeyleri son test aritmetik ortalamaları arasındaki değişim incelenmiştir. Grup değişkenine göre anlamlı bir farklılık gösterip göstermediğini belirlemek amacıyla yapılan $t$ testi sonucunda grup ortalamaları arasındaki fark istatistiksel açıdan anlamlı bulunmuştur $(\mathrm{t}=8.704$, $p=0.00<0.05)($ Tablo 1$)$.

Tablo 1'de görüldüğü gibi deney grubunun farkl1l1klara sayg1 düzeyi son test aritmetik ortalamaları $(\overline{\boldsymbol{x}}=79.56)$, kontrol grubunun farklılıklara sayg1 düzeyi son test aritmetik ortalamalarından $(\bar{x}=68.17)$ daha yüksek bulunmuştur.

Bununla birlikte FSEP uygulanan deney grubu öğrencilerinden FSEP uygulanmadan önce elde edilen farkl111klara saygı düzeyi ön test puan aritmetik ortalamalarının, program uygulandıktan sonra elde edilen farklılıklara saygı düzeyi son test aritmetik ortalamalarına göre anlamlı bir farklılık gösterip göstermediğini belirlemek amacıyla yapılan eşleştirilmiş grup $t$ testi 
sonucunda, aritmetik ortalamalar arasındaki fark istatistiksel olarak anlamlı bulunmuştur $(\mathrm{t}=-9.502, p=0.00<0.05)$. Farkl11ıklara saygı düzeyi deney grubu ön test aritmetik ortalaması $(\overline{\boldsymbol{x}}=65.61)$ farkl1lıklara saygı düzeyi son test aritmetik ortalamasından $(\overline{\boldsymbol{x}}=79.56)$ daha düşüktür. Sonuçlar Tablo 2'de gösterilmiştir.

Tablo 2. Deney ve Kontrol Gruplarının Farkl11ıklara Sayg1 Ön Test-Son Test Sonuçlarının $t$ Testi ile Karşılaştırılması

\begin{tabular}{|c|c|c|c|c|c|c|c|c|c|c|c|}
\hline $\begin{array}{l}\text { Deney } \\
\text { Grubu }\end{array}$ & $\mathbf{N}$ & $\overline{\boldsymbol{x}}$ & SS & $\mathbf{t}$ & $p$ & $\begin{array}{l}\text { Kontrol } \\
\text { Grubu }\end{array}$ & $\mathbf{N}$ & $\overline{\boldsymbol{x}}$ & SS & $\mathbf{t}$ & $p$ \\
\hline Ön Test & 39 & 65.61 & 7.30 & \multirow{2}{*}{-9.502} & \multirow{2}{*}{.00} & Ön Test & 40 & 63.85 & 7.07 & \multirow{2}{*}{-4.669} & \multirow{2}{*}{.00} \\
\hline Son Test & 39 & 79.56 & 4.98 & & & Son Test & 40 & 68.17 & 6.52 & & \\
\hline
\end{tabular}

Bir diğer inceleme kontrol grubunun farklılıklara saygı düzeyi ön test aritmetik ortalamaları ile farkl111klara sayg1 düzeyi son test aritmetik ortalamalarının karşılaştırılması ile ilgilidir. Her iki ölçüm arasında anlamlı bir farkl1lık aranmıştır. $\mathrm{Bu}$ amaçla yapılan eşleştirilmiş grup t-testi sonucunda, aritmetik ortalamalar arasındaki fark istatistiksel olarak anlamlı bulunmuştur $(\mathrm{t}=-4.669, p=0.00<0.05)$. Farkl1lıklara sayg1 düzeyi ön test ortalamaları $(\overline{\boldsymbol{x}}=63.85)$ farkl11ıklara sayg1 düzeyi son test ortalamasindan $(\overline{\boldsymbol{x}}=68.17)$ daha düşük bulunmuştur (Tablo 2).

FSEP uygulanan deney grubu ile FSEP uygulanmayan kontrol grubunun ön test ve son test aritmetik ortalamalarına bakıldığında iki grupta da anlamlı bir fark bulunmuştur (Tablo 2). Hangi grubun ortalamasında daha yüksek bir artış olduğunu anlamak için iki grubun fark puanları alınmıştır (Tablo $3)$.

Tablo 3. Deney ve Kontrol Grubuna Ait Farklılıklara Sayg1 Fark Puanlarının Karşılaştırılması

\begin{tabular}{llccccc}
\hline Grup & N & Ort. Farkı & ss & sd & t & $\boldsymbol{p}$ \\
\hline Deney & 39 & 13.948 & 9.168 & 77 & 5.574 & .00 \\
Kontrol & 40 & 4.325 & 5.859 & & & \\
\hline
\end{tabular}

Tablo 3'de deney ve kontrol grubuna ait fark puanları arasında anlamlı bir fark bulunup bulunmadığına bakıldığında, deney grubunun fark puanının ortalamas1 $(\overline{\boldsymbol{x}}=13.94)$ kontrol grubunun fark puanın ortalamasindan $(\overline{\boldsymbol{x}}=4.32)$ daha yüksek bulunmuştur (Tablo 3). Deney ve kontrol grubuna ait fark puanlarının karşılaştırılmasında deney grubu lehine anlamlı bir fark vardır $(\mathrm{t}=5.574, p=0.00<0.05)$. 
Sonuçlara bakılarak FSEP'nin farklılıklara saygı düzeyini arttırma noktasında etkili olduğu görülmektedir. Deney grubu aritmetik ortalamalarındaki olumlu farklılaşma bunu destekler niteliktedir. Kontrol grubu sonuçları incelendiğinde ise kontrol grubunun ortalamasında artış olmasına rağmen bu artış deney grubundan daha düşüktür (Tablo 3).

Araştırmanın bulgularında; FSEP uygulanan deney gurubundaki öğrencilerin farklılıklara saygı düzeyi son test puanlarının ön test puanlarına göre anlamlı bir düzeyde artması ve FSEP uygulanan deney grubu öğrencileri ve FSEP uygulanmayan kontrol grubu öğrencileri arasında, farklılıklara saygı düzeyi son test puanları arasında deney grubu lehine anlamlı bir farkın olması araştırmanın hipotezlerini doğrulamaktadır. Bu sonuç da farklılıklara saygı eğitimine olan ihtiyacı göstermektedir.

Farkl1lıklara saygı düzeyi ölçeğinin genel değerlendirmesinden sonra ölçeğin her bir boyutu ayrı ayrı ele alınmış ve sonuçlar aşağıda verilmiştir.

\section{FSEP'nin Farklılıklara Saygı Düzeyinin Aile Sosyal Yapı Farklılık- ları Boyutuna Etkisine İlişkin Bulgular}

Araştırmanın aile sosyal yapı farklılıkları boyutuna ilişkin kurulan alt problemleri "FSEP uygulanan deney grubu öğrencileri ve FSEP uygulanmayan kontrol grubu öğrencileri arasında, aile sosyal yapı farklılıkları tutum düzeyleri bakımından anlamlı bir fark var mıdır?", "FSEP uygulanan deney grubu öğrencilerinin aile sosyal yapı farklılıkları tutum düzeyleri ön test ve son test puanları arasında anlamlı bir fark var mıdır?" şeklindedir. Bu alt probleme ilişkin kurulan hipotezler ise "FSEP uygulanan deney grubu öğrencileri ve FSEP uygulanmayan kontrol grubu öğrencileri arasında aile sosyal yapı farklılıkları düzeyleri son test puanları arasında deney grubu lehine anlamlı bir farklılık vardır.", "FSEP uygulanan deney grubundaki öğrencilerin aile sosyal yapı farkl11ıkları tutum düzeyleri ön ve son test puanları arasında anlamlı bir farklılık vardır." şeklindedir. Araştırmanın bu hipotezlerini test etmek için FSEP uygulanan deney grubu ile FSEP uygulanmayan kontrol grubunun, deney grubuna FSEP uygulandıktan sonraki durumları incelenmiştir. Grup değişkenine göre yapılan $t$ testi sonucunda şu sonuçlar elde edilmiştir: 
Tablo 4. Aile Sosyal Yap1 Farklı1ıkları Ön Test ve Son Test Ortalamalarının Deney ve Kontrol Grubuna Göre $t$ Testi Kullanılarak Karşılaştırılması

\begin{tabular}{|c|c|c|c|c|c|c|c|c|c|c|c|}
\hline $\begin{array}{l}\text { Ön Test } \\
\text { Grubu }\end{array}$ & $\mathbf{N}$ & $\bar{x}$ & ss & $\mathbf{t}$ & $p$ & $\begin{array}{l}\text { Son Test } \\
\text { Grubu }\end{array}$ & $\mathbf{N}$ & $\bar{x}$ & ss & $\mathbf{t}$ & $p$ \\
\hline Deney & 39 & 20.79 & 2.86 & \multirow{2}{*}{1.373} & \multirow{2}{*}{.17} & Deney & 39 & 23.97 & 1.81 & \multirow{2}{*}{5.556} & \multirow{2}{*}{.00} \\
\hline Kontrol & 40 & 19.87 & 3.08 & & & Kontrol & 40 & 21.32 & 2.37 & & \\
\hline
\end{tabular}

Araştırmaya katılan öğrencilerden FSEP alan deney grubu öğrencileri ile FSEP almayan kontrol grubu öğrencilerinden elde edilen farklılara sayg1 düzeyinin aile sosyal yapı farkl1lıkları boyutundaki son test aritmetik ortalamaları incelenmiştir. Bu amaçla iki grup arasında grup değişkenine göre anlamlı bir farklılık aranmıştır. Bu farklılığı belirlemek amacıyla yapılan t-testi sonucunda grup ortalamaları arasındaki fark istatistiksel açıdan anlamlı bulunmuştur ( $\mathrm{t}=5.556, p=0.00<0.05)$. FSEP uygulanan deney grubunun aile sosyal yapı farklı1ıkları son test aritmetik ortalamaları $(\overline{\boldsymbol{x}}=23.97)$, FSEP uygulanmayan kontrol grubunun aile sosyal yap1 farkl11kları son test aritmetik ortalamalarından $(\bar{x}=21.32)$ daha yüksek bulunmuştur (Tablo 4$)$.

Tablo 5. Deney ve Kontrol Gruplarının Aile ve Sosyal Yapı Farklılıkları Ön Test-Son Test Sonuçlarının $t$ Testi ile Karşılaştırılması

\begin{tabular}{|c|c|c|c|c|c|c|c|c|c|c|c|}
\hline $\begin{array}{l}\text { Deney } \\
\text { Grubu }\end{array}$ & $\mathbf{N}$ & $\overline{\boldsymbol{x}}$ & ss & $\mathbf{t}$ & $p$ & $\begin{array}{l}\text { Kontrol } \\
\text { Grubu }\end{array}$ & $\mathbf{N}$ & $\bar{x}$ & SS & $\mathbf{t}$ & $p$ \\
\hline Ön Test & 39 & 20.79 & 2.86 & \multirow{2}{*}{-6.782} & \multirow{2}{*}{.00} & Ön Test & 40 & 19.87 & 3.08 & \multirow{2}{*}{-3.682} & \multirow{2}{*}{.00} \\
\hline Son Test & 39 & 23.97 & 1.81 & & & Son Test & 40 & 21.32 & 2.37 & & \\
\hline
\end{tabular}

Bir diğer bulgu ise FSEP uygulanan deney grubu öğrencileri ile ilgilidir. Deney grubuna FSEP uygulanmadan önce elde edilen aile sosyal yap1 farklılıkları ön test aritmetik ortalamaları ile program uygulandıktan sonra ede edilen aile sosyal yapı farklılıkları son test aritmetik ortalamalarını karşılaştırmak amacıyla yapılan eşleştirilmiş grup t-testi sonucunda, aritmetik ortalamalar arasındaki fark istatistiksel olarak anlamlı bulunmuştur $(\mathrm{t}=-6.782$, $p=0.0<0.05$ ). Deney grubunun aile sosyal yap 1 farklılikları son test aritmetik ortalaması $(\overline{\boldsymbol{x}}=23.97)$ aile sosyal yap 1 farkl11ıkları ön test aritmetik ortalamasindan $(\overline{\boldsymbol{x}}=20.79)$ daha yüksektir (Tablo 5).

FSEP almayan kontrol grubundaki ön test ortalamaları ile son test ortalamaları arasındaki duruma bakıldığında; farklı1ıklara sayı düzeyinin aile sosyal yapı farklılıkları boyutunda kontrol grubunun ön test aritmetik ortalamaları ile son test aritmetik ortalamaları arasındaki farklılık anlamlı bulunmuştur $(\mathrm{t}=-3.682, p=0.00<0.05)$. Kontrol grubunun son test ortalamas $(\overline{\boldsymbol{x}}=21.32)$ ön 
test ortalamasından $(\overline{\boldsymbol{x}}=19.87)$ daha yüksektir (Tablo 5).

FSEP uygulanan deney grubu ile FSEP uygulanmayan kontrol grubunun aile ve sosyal yapı farkl11ıkları boyutu ön test ve son test aritmetik ortalamalarına bakıldığında iki grupta da anlamlı bir fark bulunmuştur (Tablo 5). Hangi grubun ortalamasında daha yüksek bir artış olduğunu anlamak için iki grubun fark puanları alınmıştır (Tablo 6).

Tablo 6. Deney ve Kontrol Grubuna Ait Aile ve Sosyal Yapı Farklılıkları Boyutu Fark Puanlarının Karşıllaştırılması

\begin{tabular}{lcccccl}
\hline Grup & N & Ort. Farkı & ss & sd & t & $\boldsymbol{p}$ \\
\hline Deney & 39 & 3.179 & 2.928 & 77 & 2.831 & .00 \\
Kontrol & 40 & 1.450 & 2.490 & & &
\end{tabular}

Tablo 6'da deney ve kontrol grubuna ait aile ve sosyal yap1 farkl111kları boyutu fark puanları arasında anlamlı bir fark bulunup bulunmadığına bakıldığında, deney grubunun fark puanının ortalaması $(\bar{x}=3.17)$ kontrol grubunun fark puanın ortalamasından $(\bar{x}=1.45)$ daha yüksek bulunmuştur. Deney ve kontrol grubuna ait aile ve sosyal yap1 farklılıkları boyutu fark puanlarının karşılaştırılmasında deney grubu lehine anlamlı bir fark vardır $(\mathrm{t}=2.83$; $p=0.006<0.05$ ) (Tablo 6).

Yukarıdaki sonuçlar dikkate alındığında FSEP uygulanan deney grubunun aile sosyal yapı farklılıkları düzeylerindeki değişim dikkat çekmektedir. Deney grubunun aile sosyal yapı farklılıkları düzeyleri FSEP uygulandıktan sonra artış göstermiştir. FSEP'nin aile sosyal yapı farklılıkları düzeyini geliştirmede etkili olduğu görülmektedir. FSEP uygulanmayan kontrol grubundaki ortalamada da artış olmasına rağmen bu artış deney grubundan daha fazla değildir.

\section{FSEP'nin Farklılıklara Saygı Düzeyinin Cinsiyet Farklılıkları Bo- yutuna Etkisine İlişkin Bulgular}

Araştırmanın cinsiyet farklılıkları boyutuna ilişkin kurulan alt problemleri "FSEP uygulanan deney grubu öğrencileri ve FSEP uygulanmayan kontrol grubu öğrencileri arasında, cinsiyet farklılıkları tutum düzeyleri bakımından anlamlı bir fark var mıdır?", "FSEP uygulanan deney grubu öğrencilerinin cinsiyet farklılıkları tutum düzeyleri ön test ve son test puanları arasında anlamlı bir fark var mıdır?" şeklindedir. Bu alt probleme ilişkin kurulan hipotezler ise "FSEP uygulanan deney grubu öğrencileri ve FSEP uygulanmayan kontrol grubu öğrencileri arasında cinsiyet farklılıkları düzeyleri son test 
puanları arasında deney grubu lehine anlamlı bir farklılık vardır.", "FSEP uygulanan deney grubundaki öğrencilerin cinsiyet farklılıkları tutum düzeyleri ön ve son test puanları arasında anlamlı bir farklılık vardır." şeklindedir. Araştırmanın bu hipotezlerini test etmek için FSEP uygulanan deney grubu ile FSEP uygulanmayan kontrol grubunun, deney grubuna FSEP uygulandıktan sonraki durumları incelenmiştir. Grup değişkenine göre yapılan $t$ testi sonucunda şu sonuçlar elde edilmiştir.

Tablo 7. Cinsiyet Farklılıkları Ön Test ve Son Test Ortalamalarının Deney ve Kontrol Grubuna Göre t Testi Kullanılarak Karşılaştırılması

\begin{tabular}{|c|c|c|c|c|c|c|c|c|c|c|c|}
\hline $\begin{array}{l}\text { Ön Test } \\
\text { Grubu }\end{array}$ & $\mathbf{N}$ & $\bar{x}$ & ss & $\mathbf{t}$ & $p$ & $\begin{array}{l}\text { Son Test } \\
\text { Grubu }\end{array}$ & $\mathbf{N}$ & $\overline{\boldsymbol{x}}$ & ss & $\mathbf{t}$ & $p$ \\
\hline Deney & 39 & 9.58 & 1.69 & \multirow{2}{*}{1.421} & \multirow{2}{*}{.15} & Deney & 39 & 12.76 & 1.40 & \multirow{2}{*}{7.709} & \multirow{2}{*}{.00} \\
\hline Kontrol & 40 & 9.05 & 1.67 & & & Kontrol & 40 & 10.07 & 1.68 & & \\
\hline
\end{tabular}

Deney grubuna FSEP uygulandıktan sonra, araştırmaya katılan deney ve kontrol grubu öğrencilerinin farklılıklara saygı düzeyinin cinsiyet farklılıkları boyutunda son test aritmetik ortalamaları karşılaş̧ırılmıştır. Cinsiyet farkl11ıkları boyutunda son test aritmetik ortalamalarının grup değişkenine göre anlamlı bir farklılık gösterip göstermediği kontrol etmek amacıyla yapılan ttesti sonucunda grup ortalamaları arasındaki fark istatistiksel açıdan anlamlı bulunmuştur $(\mathrm{t}=7.709, p=0.00<0.05)$. FSEP uygulanan deney grubunun cinsiyet farklılıkları son test aritmetik ortalamaları $(\bar{x}=12.76)$, kontrol grubunun cinsiyet farkl11ıkları son test aritmetik ortalamalarından $(\overline{\boldsymbol{x}}=10.07)$ yüksek bulunmuştur (Tablo 7).

Tablo 8. Deney ve Kontrol Gruplarının Cinsiyet Farkl111kları Ön Test-Son Test Sonuçlarının t Testi ile Karşılaştırılması

\begin{tabular}{|c|c|c|c|c|c|c|c|c|c|c|c|}
\hline $\begin{array}{l}\text { Deney } \\
\text { Grubu }\end{array}$ & $\mathbf{N}$ & $\bar{x}$ & ss & $\mathbf{t}$ & $p$ & $\begin{array}{l}\text { Kontrol } \\
\text { Grubu }\end{array}$ & $\mathbf{N}$ & $\overline{\boldsymbol{x}}$ & ss & $\mathbf{t}$ & $p$ \\
\hline Ön Test & 39 & 9.58 & 1.69 & \multirow{2}{*}{-9.030} & \multirow{2}{*}{.00} & Ön Test & 40 & 9.05 & 1.67 & \multirow{2}{*}{-5.022} & \multirow{2}{*}{.00} \\
\hline Son Test & 39 & 12.76 & 1.40 & & & Son Test & 40 & 10.07 & 1.68 & & \\
\hline
\end{tabular}

Tablo 8'de görüldüğü gibi farklılıklara saygı düzeyinin cinsiyet farkl1lıkları boyutunda, FSEP uygulanan deney grubu öğrencilerinin, FSEP uygulanmadan önce elde edilen ön test aritmetik ortalamaları ile son test aritmetik ortalamalarındaki değişim incelemiştir. Deney grubuna FSEP uygulandıktan sonra elde edilen cinsiyet farklılıkları son test aritmetik ortalamalarında ön test ortalamalarına göre anlamlı bir farklılık olup olmadığı test edilmiş̧ir. $\mathrm{Bu}$ amaçla yapılan eşleştirilmiş grup $t$ testi sonucunda, aritmetik ortalamalar 
arasındaki fark istatistiksel olarak anlamlı bulunmuştur ( $\mathrm{t}=-9.030$, $p=0.00<0.05$ ). Deney grubunun cinsiyet farkl1lıkları ön test aritmetik ortalamas1 ( $\overline{\boldsymbol{x}}=9.58)$ cinsiyet farkl11ıkları son test aritmetik ortalamasından $(\bar{x}=12.76)$ daha düşüktür (Tablo 8).

Kontrol grubunda cinsiyet farkl1lıkları ön test aritmetik ortalamaları ile cinsiyet farkl11ıkları son test ortalamalarının anlamlı bir farkl11ık gösterip göstermediğini belirlemek amacıyla yapılan eşleştirilmiş grup $t$ testi sonucunda, aritmetik ortalamalar arasındaki fark istatistiksel olarak anlamlı bulunmuştur $(\mathrm{t}=-5.022, p=0.00<0.05)$. Fakat kontrol grubunun ortalamadaki artışı deney grubundan daha düşüktür (Bkz. Tablo 8).

FSEP uygulanan deney grubu ile FSEP uygulanmayan kontrol grubunun cinsiyet farklılıkları boyutu ön test ve son test aritmetik ortalamalarına bakıldı ̆̆ında iki grupta da anlamlı bir fark bulunmuştur (Tablo 8). Hangi grubun ortalamasında daha yüksek bir artış olduğunu anlamak için iki grubun fark puanları alınmıştır (Bkz. Tablo 9).

Tablo 9. Deney ve Kontrol Grubuna ait Cinsiyet Farklılıkları Boyutu Fark puanlarının Karşılaştırılması

\begin{tabular}{lcccccc}
\hline Grup & N & Ort. Farki & ss & sd & t & $\boldsymbol{p}$ \\
\hline Deney & 39 & 3.180 & 2.199 & 77 & 5.327 & .00 \\
Kontrol & 40 & 1.025 & 1.290 & & &
\end{tabular}

Tablo 9'da deney ve kontrol grubuna ait cinsiyet farkl1l1kları boyutu fark puanları arasında anlamlı bir fark bulunup bulunmadığına bakıldığında, deney grubunun fark puanının ortalaması $(\overline{\boldsymbol{x}}=3.17)$ kontrol grubunun fark puanın ortalamasından $(\overline{\boldsymbol{x}}=1.02)$ daha yüksek bulunmuştur (Tablo 9). Deney ve kontrol grubuna ait cinsiyet farklılıkları boyutu fark puanlarının karşılaştırılmasinda deney grubu lehine anlamlı bir fark vardır $(\mathrm{t}=5.32, p=0.00<0.05)$.

Deney grubundan bu boyutta elde edilen bulgular FSEP'nin etkililiğini göstermektedir. Deney grubunun FSEP uygulandıktan sonra farklılıklara saygı düzeyinin cinsiyet farklılıkları boyutunda artış olduğu görülmektedir. Kontrol grubunun verilerine bakıldığında; grubun cinsiyet farklılıkları düzeylerinde ön test ve son test ölçümleri arasında anlamlı bir fark olmasına rağmen bu fark deney grubundan daha yüksek değildir. Yukarıdaki sonuçlara bakılarak FSEP'nin farklılıklara saygı düzeyinin cinsiyet farklılıkları boyutunda etkili olduğu ifade edilebilir. FSEP'nin deney grubundaki etkisi de düşünüldügünde FSEP'ye olan ihtiyaç görülmektedir. 


\section{FSEP'nin Farklılıklara Saygı Düzeyinin Engel Farklılıkları Boyu- tuna Etkisine İlişkin Bulgular}

Araştırmanın engel farklılıkları boyutuna ilişkin kurulan alt problemleri "FSEP uygulanan deney grubu öğrencileri ve FSEP uygulanmayan kontrol grubu öğrencileri arasında, engel farklılıkları tutum düzeyleri bakımından anlamlı bir fark var mıdır?", "FSEP uygulanan deney grubu öğrencilerinin engel farklılıkları tutum düzeyleri ön test ve son test puanları arasında anlamlı bir fark var mıdır?" şeklindedir. Bu alt probleme ilişkin kurulan hipotezler ise "FSEP uygulanan deney grubu öğrencileri ve FSEP uygulanmayan kontrol grubu ögrencileri arasında engel farklılıkları düzeyleri son test puanları arasında deney grubu lehine anlamlı bir farklılık vardır.", "FSEP uygulanan deney grubundaki öğrencilerin engel farklılıkları tutum düzeyleri ön ve son test puanları arasında anlamlı bir farklılık vardır." şeklindedir. Araştırmanın bu hipotezlerini test etmek için FSEP uygulanan deney grubu ile FSEP uygulanmayan kontrol grubunun, deney grubuna FSEP uygulandiktan sonraki durumları incelenmiştir. Grup değişkenine göre yapılan $t$ testi sonucunda şu sonuçlar elde edilmiştir:

Tablo 10. Engel Farklılıkları Ön Test ve Son Test Ortalamalarının Deney ve Kontrol Grubuna Göre t Testi Kullanılarak Karşılaştırılması

\begin{tabular}{|c|c|c|c|c|c|c|c|c|c|c|c|}
\hline $\begin{array}{l}\text { Ön Test } \\
\text { Grubu }\end{array}$ & $\mathbf{N}$ & $\overline{\boldsymbol{x}}$ & ss & $\mathbf{t}$ & $p$ & $\begin{array}{l}\text { Son Test } \\
\text { Grubu }\end{array}$ & $\mathbf{N}$ & $\overline{\boldsymbol{x}}$ & ss & $\mathbf{t}$ & $p$ \\
\hline Deney & 39 & 18.00 & 2.74 & \multirow{2}{*}{0.833} & \multirow{2}{*}{.40} & Deney & 39 & 21.43 & 1.69 & \multirow[b]{2}{*}{6.151} & \multirow[b]{2}{*}{.00} \\
\hline Kontrol & 40 & 17.50 & 2.59 & & & Kontrol & 40 & 18.60 & 2.34 & & \\
\hline
\end{tabular}

FSEP'nin farklılıklara saygı düzeyinin engel farklılıkları boyutuna etkisini test etmek amaciyla FSEP uygulandıktan sonra her iki grubun engel farkl11ıkları boyutu düzeyleri incelenmiştir (Tablo 10). Bunu belirlemek için FSEP uygulanan deney grubu ile FSEP uygulanmayan kontrol grubunun son test aritmetik ortalamalarına bakılmıştır. Grup ortalamalarının grup değişkenine göre anlamlı bir farklılık gösterip göstermediğini belirlemek amacıyla ttesti yapılmıştır. Yapılan inceleme sonucunda grup ortalamaları arasındaki fark istatistiksel açıdan anlamlı bulunmuştur $(\mathrm{t}=6.151, p=0.00<0.05)$. Deney grubu son test aritmetik ortalaması $(\bar{x}=21.43)$, kontrol grubu son test aritmetik ortalamasindan $(\overline{\boldsymbol{x}}=18.60)$ yüksek bulunmuştur (Tablo 10$)$. 
Tablo 11. Deney ve Kontrol Gruplarının Engel Farklılıkları Ön Test ve Son Test Sonuçlarının t Testi ile Karşılaştırılması

\begin{tabular}{lccccclccccc}
\hline $\begin{array}{l}\text { Deney } \\
\text { Grubu }\end{array}$ & $\mathbf{N}$ & $\overline{\boldsymbol{x}}$ & $\mathbf{s s}$ & $\mathbf{t}$ & $\boldsymbol{p}$ & $\begin{array}{l}\text { Kontrol } \\
\text { Grubu }\end{array}$ & $\mathbf{N}$ & $\overline{\boldsymbol{x}}$ & $\mathbf{s s}$ & $\mathbf{t}$ & $\boldsymbol{p}$ \\
\hline Ön Test & 39 & 18.00 & 2.74 & \multirow{2}{*}{-6.667} & .00 & Ön Test & 40 & 17.50 & 2.59 & \\
Son Test & 39 & 21.43 & 1.69 & & & Son Test & 40 & 18.60 & 2.34 & -2.880 & .00 \\
\hline
\end{tabular}

FSEP uygulanan deney grubu öğrencilerinden program uygulanmadan önce elde edilen engel farklılıkları ön test puan ortalamaları ile program uygulandıktan sonra elde edilen engel farklılıkları son test puan ortalamaları karş1laştırılmıştır. Ortalamaların anlamlı bir farklılık gösterip göstermediğini belirlemek amacıyla yapılan eşleştirilmiş grup $t$ testi sonucunda, aritmetik ortalamalar arasındaki fark istatistiksel olarak anlamlı bulunmuştur ( $\mathrm{t}=-6.667$, $p=0.00<0.05)($ Tablo 11).

FSEP almayan kontrol grubunda engel farklılıkları ön test ortalamaları ile engel farklılıkları son test ortalamalarının anlamlı bir farklılık gösterip göstermediğini belirlemek amacıyla yapılan eşleştirilmiş grup $t$ testi sonucunda, aritmetik ortalamalar arasındaki fark istatistiksel olarak anlamlı bulunmuştur $(\mathrm{t}=-2.880, p=0.00<0.05)$. Kontrol grubunun engel farkl11ıkları boyutu ön test ortalaması $(\overline{\boldsymbol{x}}=17.50)$ engel farkl1lıkları boyutu son test ortalamasindan $(\overline{\boldsymbol{x}}=18.60)$ daha düşüktür (Tablo 11).

FSEP uygulanan deney grubu ile FSEP uygulanmayan kontrol grubunun engel farklılıkları boyutu ön test ve son test aritmetik ortalamalarına bakıldığında iki grupta da anlamlı bir fark bulunmuştur (Tablo 11). Hangi grubun ortalamasında daha yüksek bir artış olduğunu anlamak için iki grubun fark puanları alınmıştır (Tablo 12).

Tablo 12. Deney ve Kontrol Grubuna Ait Engel Farkl1lıkları Boyutu Fark Puanlarının Karşılaştırılması

\begin{tabular}{lcccccc}
\hline Grup & N & Ort. Farki & ss & sd & t & $\boldsymbol{p}$ \\
\hline Deney & 39 & 3.44 & 3.22 & 77 & 3.655 & .00 \\
Kontrol & 40 & 1.10 & 2.42 & 7 & \\
\hline
\end{tabular}

Tablo 12'de deney ve kontrol grubuna ait engel farkl1lıkları boyutu fark puanları arasında anlamlı bir fark bulunup bulunmadığına bakıldığında, deney grubunun fark puanının ortalaması $(\overline{\boldsymbol{x}}=3.43)$ kontrol grubunun fark puanın ortalamasından $(\overline{\boldsymbol{x}}=1.10)$ daha yüksek bulunmuştur (Tablo 12$)$. Deney ve kontrol grubuna ait engel farklılıkları boyutu fark puanlarının karşılaştırılmasında deney grubu lehine anlamlı bir fark vardır $(\mathrm{t}=3.655, p=0.00<0.05)$. 
Yukarıdaki sonuçlar dikkate alındığında FSEP uygulanan deney grubunun engel farklılıkları boyutu düzeylerindeki değişim dikkat çekmektedir. Deney grubunun engel farklılıkları boyutu düzeyleri FSEP uygulandıktan sonra artış göstermiştir. FSEP'nin farklılıklara saygı düzeyinin engel farklılıkları boyutunu geliştirmede etkili olduğu görülmektedir. FSEP uygulanmayan kontrol grubundaki ortalamada da artış olmasına rağmen bu artışın deney grubundan daha fazla olmaması FSEP'nin engel farklılıkları boyutu düzeyini geliştirmede daha etkili olduğunu destekler niteliktedir.

\section{FSEP'nin Farklııklara Saygı Düzeyinin Farklı Kültürel Geçmiş Farklılıkları Boyutuna Etkisine İlişkin Bulgular}

Araştırmanın farklı kültürel geçmiş farklılıkları boyutuna ilişkin kurulan alt problemleri "FSEP uygulanan deney grubu öğrencileri ve FSEP uygulanmayan kontrol grubu öğrencileri arasında, farklı kültürel geçmiş farklılıkları tutum düzeyleri bakımından anlamlı bir fark var mıdır?", "FSEP uygulanan deney grubu öğrencilerinin farklı kültürel geçmiş farklılıkları tutum düzeyleri ön test ve son test puanları arasında anlamlı bir fark var mıdır?" şeklindedir. Bu alt probleme ilişkin kurulan hipotezler ise "FSEP uygulanan deney grubu öğrencileri ve FSEP uygulanmayan kontrol grubu öğrencileri arasında farklı kültürel geçmiş farklılıkları düzeyleri son test puanları arasında deney grubu lehine anlamlı bir farkl11ık vardır.", "FSEP uygulanan deney grubundaki öğrencilerin farklı kültürel geçmiş farklılıkları tutum düzeyleri ön ve son test puanları arasında anlamlı bir farklılık vardır." şeklindedir. Araştırmanın bu hipotezlerini test etmek için FSEP uygulanan deney grubu ile FSEP uygulanmayan kontrol grubunun, deney grubuna FSEP uygulandıktan sonraki durumları incelenmiştir. Grup değişkenine göre yapılan $t$ testi sonucunda şu sonuçlar elde edilmiştir:

Tablo 13. Farklı Kültürel Geçmiş Farklılıkları Ön Test ve Son Test Ortalamalarının Deney ve Kontrol Grubuna Göre t Testi Kullanılarak Karşılaştırılması

\begin{tabular}{|c|c|c|c|c|c|c|c|c|c|c|c|}
\hline $\begin{array}{l}\text { Ön Test } \\
\text { Grubu }\end{array}$ & $\mathbf{N}$ & $\overline{\boldsymbol{x}}$ & SS & $\mathbf{t}$ & $p$ & $\begin{array}{l}\text { Son Test } \\
\text { Grubu }\end{array}$ & $\mathbf{N}$ & $\bar{x}$ & SS & $\mathbf{t}$ & $p$ \\
\hline Deney & 39 & 17.23 & 3.35 & \multirow[b]{2}{*}{0.279} & \multirow[b]{2}{*}{.78} & & 39 & 21.38 & 1.56 & \multirow[b]{2}{*}{6.964} & \multirow[b]{2}{*}{.00} \\
\hline Kontrol & 40 & 17.42 & 2.81 & & & Kontrol & 40 & 18.17 & 2.42 & & \\
\hline
\end{tabular}

Tablo 13'de araştırmaya katılan öğrencilerden FSEP alan deney grubu öğrencileri ile almayan kontrol grubu öğrencilerinden elde edilen farklılıklara saygı düzeyinin farklı kültürel geçmiş farklılıkları boyutundaki son test aritmetik ortalamaları incelenmiştir. $\mathrm{Bu}$ amaçla iki grup arasında grup 
değişkenine göre anlamlı bir farklılık aranmıştır. Bu farklılığı belirlemek amac1yla yapılan $t$ testi sonucunda grup ortalamaları arasındaki fark istatistiksel açıdan anlamlı bulunmuştur $(\mathrm{t}=6.964, p=0.00<0.05)$. FSEP uygulanan deney grubunun farklı kültürel geçmiş farklılıkları son test aritmetik ortalamaları $(\bar{x}=21.38)$, FSEP uygulanmayan kontrol grubunun farklı kültürel geçmiş farklılıkları son test aritmetik ortalamalarından $(\bar{x}=18.17)$ daha yüksek bulunmuştur (Tablo 13).

Tablo 14. Deney ve Kontrol Gruplarının Farklı Kültürel Geçmiş Farklılıkları Ön Test ve Son Test Sonuçlarının t Testi ile Karşılaştırılması

\begin{tabular}{lccccclccccc}
\hline $\begin{array}{l}\text { Deney } \\
\text { Grubu }\end{array}$ & $\mathbf{N}$ & $\overline{\boldsymbol{x}}$ & $\mathbf{s s}$ & $\mathbf{t}$ & $\boldsymbol{p}$ & $\begin{array}{l}\text { Kontrol } \\
\text { Grubu }\end{array}$ & $\mathbf{N}$ & $\overline{\boldsymbol{x}}$ & $\mathbf{s s}$ & $\mathbf{t}$ & $\boldsymbol{p}$ \\
\hline Ön Test & 39 & 17.23 & 3.35 & \multirow{2}{*}{-172} & \multirow{2}{*}{.00} & Ön Test & 40 & 17.42 & 2.81 & \multirow{2}{*}{ 年 } \\
Son Test & 39 & 21.38 & 1.56 & & & Son Test & 40 & 18.17 & 2.42 & .02 \\
\hline
\end{tabular}

FSEP uygulanan deney grubu öğrencilerinden program uygulanmadan önce elde edilen farklı kültürel geçmiş farklılıkları ön test aritmetik ortalamaları ile program uygulandıktan sonra elde edilen farklı kültürel geçmiş farklılikları son test aritmetik ortalamaları arasında anlamlı bir farkl111k olup olmadığı belirlenmeye çalışılmıştır. Bu amaçla yapılan eşleştirilmiş grup $t$ testi sonucunda, aritmetik ortalamalar arasındaki fark istatistiksel olarak anlamlı bulunmuştur $(\mathrm{t}=-7.172, p=0.00<0.05)($ Tablo 14).

Tablo 14'te kontrol grubunda farklı kültürel geçmiş farklılıkları ön test aritmetik ortalamaları ile farklı kültürel geçmiş farklılıkları son test aritmetik ortalamaları incelenmiştir. Ortalamalar arasında anlamlı bir farklılık belirlemek amacıyla yapılan eşleştirilmiş grup $t$ testi sonucunda, aritmetik ortalamalar arasındaki farkın istatistiksel olarak anlamlı olduğu görülmektedir $(\mathrm{t}=-2.346, p=0.02<0.05)$. Bu fark her ne kadar anlamlı olsa da deney grubundaki farktan daha düşüktür. FSEP uygulanan deney grubu ile FSEP uygulanmayan kontrol grubunun farklı kültürel geçmiş farklılıkları boyutu ön test ve son test aritmetik ortalamalarına bakıldığında iki grupta da anlamlı bir fark bulunmuştur (Tablo 14). Hangi grubun ortalamasında daha yüksek bir artış olduğunu anlamak için iki grubun fark puanları alınmıştır (Tablo 15).

Tablo 15. Deney ve Kontrol Grubuna Ait Farklı Kültürel Geçmiş Farklılıkları Boyutu Fark Puanlarının Karşılaştııılması

\begin{tabular}{lcccccl}
\hline Grup & N & Ort. Farki & ss & sd & t & $\boldsymbol{p}$ \\
\hline Deney & 39 & 4.15 & 3.61 & 77 & 5.180 & .00 \\
Kontrol & 40 & 0.75 & 2.02 & 7 & & \\
\hline
\end{tabular}


Tablo 15 'te deney ve kontrol grubuna ait farklı kültürel geçmiş farkl1lıkları boyutu fark puanları arasında anlamlı bir fark bulunup bulunmadığına bakıldığında, deney grubunun fark puanının ortalaması $(\bar{x}=4.15)$ kontrol grubunun fark puanın ortalamasından $(\overline{\boldsymbol{x}}=0.75)$ daha yüksek bulunmuştur (Tablo 15). Deney ve kontrol grubuna ait farklı kültürel geçmiş farklılıkları boyutu fark puanlarının karşılaştırılmasında deney grubu lehine anlamlı bir fark var$\operatorname{dir}(\mathrm{t}=5.180, p=0.00<0.05)$.

Yukarıdaki sonuçlar dikkate alındığında FSEP uygulanan deney grubunun farklı kültürel geçmiş farklılıkları boyutu düzeylerindeki değişim dikkat çekmektedir. Deney grubunun farklı kültürel geçmiş farklılıkları boyutu düzeyleri FSEP uygulandıktan sonra artış göstermiştir. Bu bilgilere göre FSEP'nin farklılıklara saygı düzeyinin farklı kültürel geçmiş farklılıkları boyutunu geliştirmede daha etkili bir yöntem olduğu söylenebilir.

\section{Tartışma ve Sonuç}

Bu bölümde FSEP'nin ilköğretim üçüncü sınıf öğrencilerinin farklılıklara saygı düzeylerine etkisine ilişkin elde edilen bulgular tartışılmıştır. Ayrıca bu konuda çalışma yapacak araştırmacılar için öneriler sunulmuştur. $\mathrm{Bu}$ amaçla İstanbul ili Bağcılar ilçesinde araştırmacının görev yaptığı okuldan, üçüncü sinıflardan bir grup deney bir grup kontrol grubu olarak belirlenmiştir. Her iki gruba da FSEP öncesinde ve sonrasında; Ekmişoğlu (2007) tarafından geliştirilen Farklılıklara Saygı Tutum Ölçeği uygulanmıştır. Araştırmada deney grubuna 14 hafta boyunca haftada iki ders saati olmak üzere araştırmacı tarafindan FSEP uygulanmıştır. Kontrol grubuna 14 hafta süresinde herhangi bir işlem yapılmamıştır. FSEP uygulandıktan sonra elde edilen veriler farkl1lıklara saygı eğitimi programının öğrencilerin farklılıklara saygı düzeyini arttırmada olumlu etkisinin olduğu görülmüş̧ür.

Üner (2011), yaptığı araştırmada öğretmenlerin ortak görüşleri; farkl1lara saygı eğitimi kazanımlarının öğrencilerin tüm gelişim alanlarına (sosyal duygusal alan, bilişsel alan, psikomotor alan, dil alanı, öz bakım becerileri) katk1 sağladığı düşüncesindedir. Bununla birlikte bu araştırmanın sonuçlarına göre farklılıklara saygı eğitiminin öğrencilere kendini tanıma kazanımı sağladığı, özbenlik geliştirdiği, eleştirel düşünme kazanımı edindikleri, empati kurma kazanımı sağladığı ve sosyal yeterliliği arttırdığı ortaya konmuştur.

Ekmişoğlu (2007), araştırmasında öğretmen fikirlerini ortaya koyan bulgular doğrultusunda, öncelikle öğretmenlerin farklılık kavramları 
konusunda çocukların farkındalıklarını arttırmaya yönelik yapacakları çalışmaları, materyallerle desteklemesi gerektiği ortaya çıkmıştır.

Araştırmanın deneysel sürecinde deney grubuna farklılıklara saygı eğitimi verilirken yeterli düzeyde materyal desteğinden yararlanılmıştır. Araştırmanın ilk hipotezinin doğrulanmasında materyal desteğinin katkısı kaçınılmazdır.

Araştırmanın ilk hipotezi "FSEP uygulanan deney grubundaki öğrencilerin farklılıklara saygı düzeyi son test puanları ön test puanlarına göre anlamlı bir düzeyde artacaktır.” şeklinde belirlenmiştir. Bu hipoteze ilişkin bulgular; FSEP'nin deney grubu öğrencilerin farkl111klara saygı düzeylerine etki ettiğini göstermektedir. Deney grubunun farklılıklara saygı düzeyleri FSEP uygulamadan önceki durumlarına göre anlamlı bir şekilde artmıştır. Böylece araştırmanın birinci hipotezi kabul edilmiştir.

Araştırmanın ikinci hipotezi, "FSEP uygulanan deney grubu öğrencileri ve FSEP uygulanmayan kontrol grubu öğrencileri arasında, farklılıklara saygı düzeyi son test puanları arasında anlamlı bir farklılık vardır." şeklinde belirlenmiştir. FSEP uygulanan deney grubu öğrencileri ve FSEP uygulanmayan kontrol grubu öğrencileri arasında farklılıklara saygı ön test puanları arasında anlamlı bir fark yokken son test puanları arasında anlamlı bir farklılık mevcuttur. Araştırmada elde edilen bulgulara bakılarak FSEP'nin uygulandığı öğrencilerde, FSEP uygulanmayan öğrencilere göre, FSEP lehine bir sonuç verdiği görülmektedir. Bu sonuçlar araştırmanın ikinci hipotezinin kabul edildiğini göstermektedir.

Birinci ve ikinci hipotezlerin doğrulanmasıyla deneysel süreçte uyguladığımız FSEP'nin öğrencilerin farklılıklara saygı düzeylerine olumlu yönde etki ettiği sonuca ulaşı1mıştır. Bu sonuçta bize FSEP'nin işe yararlılığını göstermektedir.

Araştırmadaki farklılıklara saygı eğitimi alt boyutlarından birisi aile sosyal yapı farklılıklarıdır. Farklılıklara sayg1 eğitiminde aile sosyal yapı farkl11ıkları boyutuna ait etkinlikler sayesinde çocuklar da birbirlerinin yaşam biçimlerini, farklı aile yapılarını ve farklı meslekleri tanıacak ve bu farklılıklara saygı duyacaktır.

Araştırmanın deneysel sürecinde deney grubuna, aile ve sosyal yapı farklılıkları boyutuna ait etkinlikler başarıyla uygulanmıştır. Bu uygulama sonucunda ise "FSEP uygulanan deney grubundaki öğrencilerin aile sosyal yapı 
farklılıkları düzeyleri ön ve son test puanları arasında anlamlı bir farklılık vardır." hipotezi ve "FSEP uygulanan deney grubu öğrencileri ve FSEP uygulanmayan kontrol grubu öğrencileri arasında, aile sosyal yapı farklılıkları düzeyleri son test puanları arasında anlamlı bir farklılık vardır." hipotezi doğrulanmıştır. Bu sonuçla da FSEP'de aile ve sosyal yapı farklılıkları boyutuna ilişkin öğrencilere uygulanan etkinliklerin öğrencilerin aile ve sosyal yapı farklılıkları düzeyini arttırdığg söylenebilir. Bu da FSEP'de aile ve sosyal yapı farkl1lıkları boyutuna dair hazırlanmış etkinliklerin işe yararlılığını göstermektedir.

Ekmişoğlu (2007), araştırmasında öğretmenlere yaptığı görüşmelerde öğretmenlerin çoğu farklı kültürdeki ailelerin farklı yaşantılara sahip olduğunu ve bu eğitimle farklı kültürlerin birleştirilip harmanlanabileceğini belirtmişlerdir. Kendi araştırmamızda ise Ekmişoğlu (2007)'nun araştırmasında elde ettiği bu bilgilerden de yola çıkarak farklı kültürlere ait, çocukların düzeyine uygun aile sosyal yapı farklılıklarına ilişkin etkinlikler hazırlanmıştır. Hazırlanan bu etkinliklerin deney grubundaki öğrencilerin aile sosyal yapı farklı1ıkları boyutunu arttırdığı sonucuna ulaşılmıştır. Ulaşılan bu sonuç Ekmişoğlu (2007)'nun araştırma sonuçlarını da destekler niteliktedir.

Araştırmadaki farklı1ıklara saygı eğitimi alt boyutlarından bir tanesi de cinsiyet farklılıkları boyutudur. Araştırmanın deneysel sürecinde deney grubuna, cinsiyet farklı1ıklarına ait etkinlikler başarıyla uygulanmıştır. Bu uygulama sonucunda ise "FSEP uygulanan deney grubundaki öğrencilerin cinsiyet farklılıkları düzeyleri ön ve son test puanları arasında anlamlı bir farklılık vardır." hipotezi ve "FSEP uygulanan deney grubu öğrencileri ve FSEP uygulanmayan kontrol grubu öğrencileri arasında, cinsiyet farklılıkları düzeyleri son test puanları arasında anlamlı bir farklılık vardır." hipotezi doğrulanmıştır. Bu sonuçla da FSEP'de cinsiyet farklılıkları boyutuna ilişkin öğrencilere uygulanan etkinliklerin öğrencilerin cinsiyet farklılıkları düzeyini arttırdığı söylenebilir. Bu da FSEP'de cinsiyet farklılıkları boyutuna dair hazırlanmış etkinliklerin işe yararlılığını göstermektedir.

Üner (2011)'in yaptığı araştırmada cinsel kimliğe karşı tutumlar hakkında öğretmenlerin tamamı çocukların bu eğitimi aldıktan sonra cinsel kimliklerinin farkındalığına sahip olduklarını belirtmişlerdir. Öğretmenler, öğrencileri arasında özellikle erkek öğrencilerin kızlara karşı cinsel ayrımcılıkta bulunduğunu belirtmişlerdir. Oyun oynayan erkek çocukların arasına kızları hiç almadıkları konusunda ortak görüş bildirmişlerdir. Üner (2011)'in araştırma sonuçlarına baktığımızda eğitimin cinsel kimlik farkındalığında önemli bir 
yere sahip olduğu söylenebilir. Kendi araştırmamızda bu sonuçtan yola çıkarak öğrencilerin cinsiyet farklılıkları tutumlarını olumlu yönde geliştirmek için 3. sınıf düzeyine uygun cinsiyet farklılıklarına ilişkin etkinlikler hazırlanmıştır. Bu etkinlikler eğitim sürecinde öğrencilere aktarılmış ve öğrencilerin cinsiyet farklılıkları tutumlarını olumlu yönde geliştirmiştir. Üner (2011)'in araştırmasında, öğrencilerin eğitim aldıktan sonra cinsel kimlik farkındalıklarının geliştiği sonucuyla kendi araştırmamızda eğitim aldıktan sonra öğrencilerin cinsiyet farklılıkları tutumlarının gelişmesi, iki araştırmanın birbirlerini doğruladığının göstergesidir.

Araştırmada farklılıklara saygı eğitim alt boyutlarından olan engel farkl11ıkları etkinlikleri deney grubu öğrencilerine başarıyla uygulanmıştır. Araştırma sonucunda ise "FSEP uygulanan deney grubundaki öğrencilerin engel farklılıkları düzeyleri ön ve son test puanları arasında anlamlı bir farklılık vardir." hipotezi ve "FSEP uygulanan deney grubu öğrencileri ve FSEP uygulanmayan kontrol grubu öğrencileri arasında, engel farklılıkları düzeyleri son test puanları arasında anlamlı bir farklılık vardır." hipotezi doğrulanmıştır. Bu sonuçla da FSEP'de engel farklılıkları boyutuna ilişkin öğrencilere uygulanan etkinliklerin öğrencilerin engel farklılıkları düzeyini arttırdığı söylenebilir. Bu da FSEP'de engel farkl111kları boyutuna dair hazırlanmış etkinliklerin işe yararlılığını göstermektedir.

Üner (2011)'in araştırmasında öğretmen görüşlerine göre çocukların ilk fark ettikleri farklılıkların başında bedensel engel durumları gelmektedir. Çocuklar engel durumunun kendilerinde de oluşabileceği konusunda korkular yaşarlar. Elde edilen bulgular bu savı destekler niteliktedir. Çocuklar her çeşit engel durumlarına yönelik önyargı davranışlar sergilemeye meyilli oldukları için, farklılığın bu boyutuna yönelik olumsuz davranışlara erken yaşlarda başladıkları sonucu ortaya çıkmaktadır.

Ekmişoğlu (2007), yaptığı araştırmada öğretmenlerle yaptığı görüşmeler sonucunda; öğretmenlerin birçoğu, farklılıklara saygı eğitimi konusu çocuklara kazandırıldıktan sonra çocukların engellilere karşı daha saygılı olduklarını, onlarla empati kurabildiklerini ve onlara daha da yardımsever davrandıklarını belirtmişlerdir.

Üner (2011)'in ve Ekmişoğlu (2007)'nun araştırma sonuçlarından yola çıkarak 3. sınıf düzeyine uygun engel farklılıklarıyla ilgili etkinlikler hazırlanmış ve deney grubu öğrencilerine uygulanmıştır. Uygulama sonucunda deney grubu öğrencilerinin engel farklılıklarına ilişkin tutumlarının arttığı sonucuna 
ulaşılmıştır. Sonuç olarak da Ekmişoğlu (2007) ve Üner (2011)'in araştırmalarında olduğu gibi bu araştırmada da öğrencilerin engellilere karşı daha sayg1lı ve daha yardımsever olabilmeleri, onların yerine kendilerini koyabilmeleri konusunda farklılıklara saygı eğitimin önemli bir yere sahip olduğu söylenebilir.

Araştırmada farklılıklara saygı eğitim alt boyutlarından olan farklı kültürel geçmiş farklılıkları etkinlikleri deney grubu öğrencilerine başarıyla uygulanmıştır. Araştırma sonucunda ise "FSEP uygulanan deney grubundaki öğrencilerin farklı kültürel geçmiş farklılıkları düzeyleri ön ve son test puanları arasında anlamlı bir farklılık vardır." hipotezi ve "FSEP uygulanan deney grubu öğrencileri ve FSEP uygulanmayan kontrol grubu öğrencileri arasında, farklı kültürel geçmiş farklılıkları düzeyleri son test puanları arasında anlamlı bir farklılık vardır." hipotezi doğrulanmıştır. Bu sonuçla da FSEP'de farklı kültürel geçmiş farkl1lıkları boyutuna ilişkin öğrencilere uygulanan etkinliklerin öğrencilerin farklı kültürel geçmiş farklılıkları düzeyini arttırdığı söylenebilir. Bu da FSEP'te farklı kültürel geçmiş farklılıkları boyutuna dair hazırlanmış etkinliklerin işe yararlılığını göstermektedir.

Araştırmanın üçüncü hipotezi "FSEP uygulanan deney grubundaki öğrencilerin farklılıklara saygı boyutları (aile sosyal yapı farklılıkları, cinsiyet farklılıkları, engel farklılıkları, farklı kültürel geçmiş farklılıkları) düzeyleri ön ve son test puanları arasında anlamlı bir farklılık vardır." şeklinde belirlenmiştir. $\mathrm{Bu}$ hipoteze ilişkin bulgular, FSEP'nin lehine görünmektedir. FSEP'nin deney grubu öğrencilerinin farklılıklara saygı boyutlarından; aile sosyal yapı farkl111kları, cinsiyet farklılıkları, engel farkl11ıkları, farklı kültürel geçmiş farklı1ıkları boyutlarında etkili olduğu görülmüştür. FSEP alan deney grubunun farklılıklara saygı düzeylerinin; aile sosyal yapı farklılıkları, cinsiyet farklılıkları, engel farklılıkları, farklı kültürel geçmiş farklılıkları boyutları düzeyleri FSEP almayan kontrol grubuna göre anlamlı bir şekilde artmıştır. Böylece araştırmanın üçüncü hipotezi de kabul edilmiştir.

Araştırmanın son hipotezi, "FSEP uygulanan deney grubu öğrencileri ve FSEP uygulanmayan kontrol grubu öğrencileri arasında, farklılıklara sayg1 boyutları (aile sosyal yapı farkl11ıkları, cinsiyet farklılıkları, engel farklılıkları, farklı kültürel geçmiş farklılıkları) düzeyleri son test puanları arasında anlamlı bir farklılık vardır." şeklinde belirlenmiştir. Bu hipoteze ilişkin bulgular, öğrencilerin aile sosyal yapı farklılıkları, cinsiyet faklılıkları, engel farklılıkları, farklı kültürel geçmiş farklılıkları boyutlarında etki yaratıldığını 
göstermektedir. FSEP alan deney grubunun farkl11ıklara saygı düzeylerinin; aile sosyal yapı farklılıkları, cinsiyet farklılıkları, engel farklılıkları, farklı kültürel geçmiş farklılıkları boyutları düzeyleri son test aritmetik ortalamaları kontrol grubuna göre anlamlı bir şekilde arttığını göstermektedir. Bu sonuçlar dahilinde araştırmanın son hipotezi kabul edilmiştir.

\section{Kaynakça}

Atasoy, Z. (2012). Farklllıkların yönetimi: Üniversite ögrencilerinin ayrımcllık algısının öğrenci başarı düzeyine etkisi üzerine bir araştırma. Yayınlanmamış yüksek lisans tezi, Karamanoğlu Mehmetbey Üniversitesi Sosyal Bilimler Enstitüsü.

Büyüköztürk, Ş. (2014). Deneysel desenler. Ankara: Pegem Akademi.

Büyüköztürk, Ş., Çakmak, E. K., Akgün, Ö. E., Karadeniz, Ş. ve Demirel, F. (2009). Bilimsel araştırma yöntemleri. Ankara: Pegem Akademi.

Çubukçu, Z. ve Gültekin, K. (2002). İlköğretimde öğrencilere kazandırılması gereken sosyal beceriler. Bilig Türk Dünyası Sosyal Bilimler Dergisi, 1, 34-52.

Derman-Sparks, L. (1989) Anti-bias curriculum: Tools for empowering young children, Washington: DC, NAEYC.

Derman-Sparks, L. (2010). Anti-bias education for young children and ourselves. Washington, DC: National Association for the Education of Young Children.

Derman-Sparks, L. ve Edwards, J. O. (2010). Anti-bias education for young children and ourselves. Washington, DC: National Association for the Education of Young Children.

Ekmişoğlu, M. (2007). Erken çocukluk döneminde farkllılıklara saygı eğitimi kavamı hakkında ögretmen görüşlerinin incelenmesi ve Farklılıklara Saygı Ölçeği'nin geçerlik güvenirlik çalışması. Yayınlanmamış yüksek lisans tezi, Onsekiz Mart Üniversitesi Sosyal Bilimler Enstitüsü.

Gomolla, M. ve Radtke, F. O. (2002). Institutionelle diskriminierun die herstellung ethnischer differenz in der schule. Opladen: Leske\&Budrich.

Hall, N. S. (1999). Creative resources for the anti-bias classroom. United States of America: Delmar Publishers.

Karasar, N. (2012). Bilimsel araştırma yöntemi (24. bask1). Ankara: Nobel. 
KEDV, (2006). Erken çocuklukta farklılıklara saygl eğitimi el kitabı. İstanbul: Derin Yayınları.

Ramsey, P. G. (1987). Teaching and learning in a diverse world - multiculturel education for young children. New York: Teachers College Pres.

Toprak, G. (2008). Öğretmenlerin çokkültürlü tutum ölçeğinden güvenirlik ve geçerlik çalışması. Yayınlanmamış yüksek lisans tezi, Gaziosmanpaşa Üniversitesi Sosyal Bilimler Enstitüsü.

Üner, E. (2011). Okul öncesi eğitim programındaki 36-72 aylık çocuklara farklılıklara saygı eğitimi kazandırmanın öğretmen görüşleri doğrultusunda değerlendirilmesi. Yayınlanmamış yüksek lisans tezi, Erciyes Üniversitesi Eğitim Bilimleri Anabilim Dalı.

Wolpert, E. (2002). Redefining the Norm: Early childhood anti-bias strategies. Lee, D. Menkart ve M. Okazawa- Rey, (Ed.), Beyond heroes and holidays: A paractical guide to K-12 anti-racist, multicultural education and staff development içinde (187-200). Washington, DC: Teaching for Change.

Yıldız, N. (2008). Kültürler arası eğitim. Eğitim Bilim Toplum Dergisi, 6(22), 52-89. 